Al Maal : Journal of Islamic Economics and Banking

http://jurnal.umt.ac.id/index.php/jieb

E-ISSN : $2580-3816$

Vol : No 1 Vol 2 Bulan Januari Tahun 2020

Hlm : $144-163$

DOI $\quad$ : $10.31000 /$ almaal.v1i2.1847

\title{
Pengaruh Bauran Pemasaran Syariah dan Label Halal terhadap Keputusan Pembelian
}

\author{
Rika Paujiah ${ }^{1 *}$, Ahmad Mulyadi Kosim², Syarifah Gustiawati ${ }^{3}$ \\ ${ }^{123}$ Program Studi Ekonomi Syariah, FAI-UIKA, Bogor, Indonesia \\ *rikapaujiah0609@gmail.com
}

\begin{abstract}
This study was conducted to examine the effect of the sharia marketing mix variables and halal label on purchase decisions at d'BestO city of Bogor. This study uses a quantitative method. The sample was 86 respondents who are consumers of products d'BestO in Bogor. Analysis of the data used in this research is multiple regression analysis. The results of this study show that: sharia marketing mix significantly influence the purchase decision is evidenced bythat the value of the variable t on sharia marketing mix is 4.090 with a significance level of 0.000. Because the value of $t$ is greater than t table is $4.090>1.988$ and 0.000 significance value $<0.05$. And halal label significantly influence the purchase decision is evidenced by the value of the variable ton halal label is 3.739 with a significance level of 0.000. Because the value of t is greater than table is 3.739> 1.988 and 0.000 significance value $<0.05$. sharia marketing mix and halal label jointly significant effect on purchase decisions this is evidenced by the significant value of the smaller $F$-test of 0.05 is equal to $0.000(0.000<0,05)$ so that it can be concluded that the sharia marketing mix and halal label significant influence on purchase decisions.
\end{abstract}

Keywords : Sharia Marketing Mix; Halal Label; Purchase Decision

\begin{abstract}
ABSTRAK
Penelitian ini dilakukan untuk menguji pengaruh variabel bauran pemasaran syariah dan label halal terhadap keputusan pembelian di d'BestO Kota Bogor. Penelitian ini menggunakan metode kuantitatif. Sampel yang digunakan berjumlah 86 responden yang merupakan konsumen produk d'BestO di Kota Bogor. Analisis data yang digunakan dalam penelitian ini adalah analisis regresi berganda. Hasil dari penelitian ini menunjukkan bahwa : Bauran Pemasaran Syariah berpengaruh secara signifikan terhadap Keputusan Pembelian dibuktikan dengan bahwa nilai $t$ hitung pada variabel Bauran Pemasaran Syariah adalah 4,090 dengan tingkat signifikansi sebesar 0,000. Karena nilai t hitung lebih besar dari t tabel yaitu 4,090 > 1,988 dan nilai signifikansinya $0,000<0,05$. Dan Label Halal berpengaruh secara signifikan terhadap Keputusan Pembelian dibuktikan dengan nilai t hitung pada variabel label halal adalah 3,739 dengan tingkat signifikansi sebesar 0,000. Karena nilai t hitung lebih besar dari t tabel yaitu 3,739 > 1,988 dan nilai signifikansinya 0,000 < 0,05. Bauran Pemasaran Syariah dan Label Halal secara bersama-sama berpengaruh signifikan terhadap keputusan pembelian hal ini dibuktikan dengan nilai signifikansi dari uji F yang lebih kecil dari 0,05 yaitu sebesar 0,000 $(0,000<0,05)$ sehingga dapat disimpulkan bahwa Bauran Pemasaran Syariah dan Label Halal berpengaruh signifikan terhadap keputusan pembelian.
\end{abstract}

Kata kunci : Bauran Pemasaran Syariah; Label Halal; Keputusan Pembelian 


\section{Pendahuluan}

Perkembangan bisnis di era globalisasi sekarang ini pada umumnya, memudahkan manusia untuk melakukan aktivitas bisnis salah satunya di bidang kuliner yaitu makanan cepat saji. Jenis restoran yang menyediakan makanan cepat saji atau siap saji disebut restoran fast food. Usaha restoran dewasa ini menunjukkan perkembangan yang relatif pesat, terbukti dengan semakin banyaknya restoran siap saji di Bogor. Hal tersebut mengidentifikasikan bahwa intensitas dalam restoran semakin kuat (Gunawan, 2013).

Dalam pemasaran perusahaan dituntut untuk mengembangkan perusahaannya sehingga dapat memenuhi kebutuhan dan keinginan konsumen sehingga dapat memuaskan konsumen. Untuk bisa memuaskan konsumen produsen harus memusatkan perhatiannya kepada selera konsumen, produsen harus memperhatikan needs dan want dari konsumen, sehingga produk bisa dipasarkan di pasaran. Sebelum itu, produsen terlebih dahulu harus bisa memahami perilaku konsumen terlebih dahulu agar dapat memasarkan produknya (Heryanto, 2015).

Meningkatnya permintaan makanan cepat saji membuat persaingan bisnis semakin meningkat. Dunia bisnis tidak dapat dipisahkan dari aktivitas persaingan. Dengan kata lain, persaingan dalam bisnis tidak dapat dihindarkan. Dalam menghadapi persaingan yang semakin kompetitif banyak perusahaan yang melakukan berbagai cara untuk mendapatkan calon pelanggan yaitu, melakukan penipuan dalam kegiatan promosinya, melakukan kecurangan dengan menjelek-jelekkan pesaingnya agar masyarakat tidak membeli produknya dan lain sebagainya. Seorang pebisnis muslim harus dapat memahami bahwa dalam ajaran Islam dianjurkan untuk melakukan perlombaan dalam mencari kebaikan dalam segala hal, termasuk dalam berbisnis. Oleh karena itu, pebisnis muslim harus berusaha menghadapinya tanpa perlu merugikan orang lain (Zainal, Djaelani, Basalamah, Yusran dan Veithzal, 2017).

Dalam sebuah bisnis pemasaran sangatlah berperan penting, baik dalam memasarkan barang ataupun jasa. Haruslah menggunakan teknik yang tepat untuk menarik minat konsumen (Robiah, 2017). Marketing mix adalah satu set taktik yang spesifik, detail, orientasi pada aksi dalam menangani strategi harga, produk, promosi dan distribusi yang akan diikuti oleh perusahaan untuk menjangkau dan memuaskan keputusan target pasarnya. Perencanaan marketing mix harus dilakukan dengan matang untuk membentuk citra dan persepsi yang baik (Fatoni, 2014).

Bauran pemasaran syariah sebenarnya sama saja dengan bauran pemasaran konvensional perbedaanya terletak pada implementasinya. karena pada setiap unsur variabel dalam bauran pemasaran syariah di dasarkan pada perspektif Islam.Pemasaran syariah adalah pemasaran yang mengedepankan nilai-nilai keadilan dan kejujuran dan berpegang teguh pada Al-Qur'an dan hadits shahih. Sehingga segala proses transaksinya terpelihara dari hal-hal terlarang oleh ketentuan syariah. Dalam pemasaran syariah perusahaan tidak hanya berorientasi pada keuntungan semata, namun turut pula berorientasi pada tujuan lainnya yaitu keberkahan. Dan semata-mata untuk mendapatkan keridhaan Allah SWT (Huda Hudori, Fahlevi, Badrussa'diyah, Mazaya dan Sugiarti, 2017).

Kehalalan akan menjadi penting dalam kajian pemasaran di Indonesia, karena saat ini konsumen akan memperhatikan label halal yang tertera pada produk yang diperjual belikan pada pasar. Umat muslim percaya bahwa dengan mengkonsumsi makanan yang halal akan menjadi berkah dan sehat untuk manusia. Kehalalan merupakan pokok utama 
bagi umat muslim untuk beribadah agar senantiasa manusia selalu dijalan yang benar, disamping itu kehalalan terdapat dalam Al-Qur'an dan hadist. Islam mengajarkan kita agar senantiasa untuk mengkonsumsi yang ada dimuka bumi yang serba halal dan baik, baik makanan dan minuman (Widyaningrum, 2018).

Ketiadaan label halal pada suatu produk akan membuat konsumen muslim berhatihati dalam memutuskan konsumsi terhadap produk tersebut. Label halal pada kemasan produk yang ada di Indonesia adalah sebuah logo yang tersusun dari huruf-huruf Arab yang membentuk kata halal dalam sebuah lingkaran. (Bulan dan Rizal, 2016). Label halal yang terdapat pada kemasan produk, akan mempermudah konsumen dalam mengidentifikasi produk dan memberikan rasa aman dalam memutuskan pembelian. Pemberian label halal pada produk, sedikit banyak akan mengurangi keraguan konsumen akan kehalalan produk yang dibeli (Rafita, 2017).

Proses pengambilan keputusan pada umumnya seorang konsumen akan berusaha untuk mencari informasi tentang bagaimana mengambil keputusan pembelian yang tepat. Dewasa ini konsumen sangat kritis dalam mencari dan menggali informasi tentang produk yang akan digunakan. Dari segi kualitas, setiap Muslim harus memperhatikan halal tidaknya sebuah produk dan baik (tayyib). Pemahaman yang semakin baik tentang agama semakin membuat umat Islam menjadi semakin selektif dalam pemilihan produk yang dikonsumsi (Alfian dan Marpaung, 2017).

Menurut penelitian yang dilakukan oleh Istianah, Nawawi dan Gustiawati (2018) bahwa ada pengaruh secara positif dan signifikan antara syaria marketing mix terhadap kepercayaan konsumen dan keputusan pembelian pada online shop Tiws.id. Menurut penelitian yang dilakukan Larasati, Hamdani dan Lisnawati (2019) bahwa label halal berpengaruh terhadap keputusan muslimah bogor untuk membeli produk kecantikan. Penelitian yang dilakukan Tarigan (2016) bahwa gaya hidup, label halal dan harga berpangaruh terhadap keputusan pembelian kosmetik wardah pada mahasiswa program studi manajemen fakultas ekonomi universitas Medan area Medan. Adapun tujuan penelitian ini berbeda dengan penelitian sebelumnya yaitu untuk mengetahui pengaruh bauran pemasaran syariah dan label halal terhadap keputusan pembelian di Restoran d'BestO Bondes Bogor.

\section{KAJIAN LITERATUR Pemasaran Syariah}

Arti dari marketing adalah pemasaran. Kata market sendiri berarti pasar, sehingga penjabaran kata marketing mencakup segala kegiatan manusia yang terjadi sehubungan dengan pasar. Segala kegiatan di sini bukan hanya sekedar menjual suatu produk, tetapi dimulai dari mengidentifikasi kebutuhan konsumen, mengembangkan produk yang tepat, menetapkan harga yang sesuai, serta melaksanakan distribusi dan promosi yang efektif. Setelah melalui tahapan-tahapan marketing itu, suatu produk akan diterima oleh konsumen di pasar (Murtie, 2011).

Menurut Djamil (2013), kata syariah berasal dari bahasa Arab, dari akar kata syara' $a$, yang memiliki berbagai macam arti, antara lain: jalan, cara, dan aturan. Syariah merupakan suatu sistem aturan yang didasarkan pada ajaran Allah (Al-Qur'an) dan Rasul (Sunnah-Nya), yang menyangkut seluruh aspek kehidupan umat manusia, baik menyangkut hubungan manusia dengan Allah maupun hubungan manusia dengan 
manusia dan alam lingkungannya. Dalam perkembangan selanjutnya kata syariah digunakan untuk menggunakan hukum-hukum Islam, baik yang ditetapkan langsung oleh Al-Qur'an dan Sunnah, maupun yang dicampuri pemikiran manusia (ijtihad).

Dari definisi dua kata tersebut maka dapat disimpulkan bahwa pemasaran syariah adalah sebuah disiplin bisnis strategis yang mengarahkan proses penciptaan, penawaran dan perubahan value dari suatu inisiator kepada stakeholders-nya, yang dalam keseluruhan prosesnya sesuai dengan akad dan prinsip-prinsip muamalah (bisnis) dalam Islam. Dan merupakan salah satu bentuk muamalah yang dibenarkan dalam Islam, sepanjang dalam segala proses transaksinya terpelihara dari hal-hal yang terlarang oleh ketentuan syariah (Huda, Hudori, Fahlevi, Badrussa'diyah, Mazaya dan Sugiarti, 2017). Selain itu, dalam syariah marketing, perusahaan tidak untuk mendapatkan keuntungan semata saja, akan tetapi juga untuk mendapatkan keberkahan dan mencari keridhaan Allah. Sehingga seluruh transaksinya menjadi ibadah dihadapan Allah SWT.

\section{Bauran Pemasaran Syariah}

Menurut (Priansa, 2017), alat yang digunakan oleh perusahaan dalam kegiatan pemasaran disebut bauran pemasaran atau marketing mix. Disebut bauran (mix) karena kombinasi atau gabungan dari beberapa alat pemasaran. Manajemen pemasaran mengenal empat strategi pemasaran yang lazim disebut bauran pemasaran 4P, yaitu produk (product), harga (price), tempat (place), dan promosi (promotion).

Menurut Fatoni (2014) bauran pemasaran (marketing mix)adalah satu set taktik yang spesifik, detail, orientasi pada aksi dalam menangani strategi harga, produk, promosi dan distribusi yang akan diikuti oleh perusahaan untuk menjangkau serta memuaskan keputusan target pasarnya. Perencanaan marketing mix harus dilakukan dengan matang untuk membentuk citra dan persepsi yang baik.

Bauran pemasaran syariah tidak jauh berbeda dengan bauran pemasaran pada umumnya, perbedaannya hanya terletak pada implementasinya, karena setiap variabel dalam bauran pemasaran syariah pelaksanaanya didasarkan atas perspektif Islam (Huda Hudori, Fahlevi, Badrussa'diyah, Mazaya dan sugiarti, 2017). Dan untuk keberhasilan suatu bisnis, terdapat 4 unsur bauran pemasaran (Marketing Mix-4p) yaitu: Produk (Product), Harga (Price), Tempat (Place), dan Promosi (Promotion), yang diantaranya:

\section{Product (Produk)}

Menurut Ishak dan Abdullah (2012) dalam Asnawi dan Fanani (2017), produk adalah bagian dari elemen marketing mix. Secara eksplisit produk yang dilarang dalam Al-Qur'an dan Sunah nabi adalah bangkai, daging babi, darah hewan (QS [5]:4), minuman beralkohol (QS [2]:219), perjudian, prostitusi, dan penggunaan bunga dalam praktik keuangan dan perbankan (QS [2]:275). Dalam perspektif Islamic marketing produk harus memenuhi ketentuan halal, tidak menyebabkan pikiran kotor atau rusak, tidak mengganggu, tidak mengandung unsur riba dan maysir, bermoral, produk harus dalam kepemilikan yang sah, produk harus diserahterimakan dengan jelas karena penjualan produk fiktif tidak dapat dibenarkan (contoh penjualan ikan di sungai) dan produk harus tepat secara kuantitas dan kualitasnya.

Menurut Wijayanti (2017), produk adalah sesuatu yang diperjualbelikan dengan tujuan untuk mendapatkan keuntungan dari sesuatu hasil kreativitas seseorang, tim marketing atau perusahaan. Produk barang atau jasa ini biasanya merupakan alat untuk 
memenuhi keinginan dan kebutuhan pelanggan serta bentuknya berwujud, dapat dilihat dan menarik. Produk yang dibuat haruslah bermanfaat bagi konsumen.

Produk mencakup beberapa nilai, diantaranya adalah kegunaan produk, kualitas produk, ketersediaan produk, dan harga produk itu sendiri. Dalam memasarkan, Muhammad saw selalu menjelaskan dengan baik kepada semua pembelinya akan kelebihan dan kekurangan produk yang ia jual. Kejujuran memegang peranan utama dalam perniagaan Muhammad saw. Dengan selalu jujur kepada konsumen mengenai baik buruknya suatu produk akan membuat konsumen percaya (Robiah, 2017).

Dalam pemasaran Islam, produk harus murni dan diperbolehkan (halal). Ini termasuk fakta bahwa tidak boleh ada bahan berbahaya dalam produk yang dapat mempengaruhi konsumen dan masyarakat secara negatif. Pada dasarnya berarti produksi produk harus dipandu oleh kode etik Islam, yang didorong oleh Islam. Dalam perspektif Islam pemasar harus memberitahu pembeli tentang kualitas dan cacat produk sebelum melakukan transaksi. Jika penjual atau pembeli berbohong atau menyembunyikan sesuatu dari konsumen, maka tidak dianggap sebagai halal (dibolehkan) transaksi bisnis. Oleh karena itu perusahaan harus jujur dan etis dalam rangka memberikan kualitas terbaik dari produk atau jasa (Ahmed dan Rahman, 2015).

Menurut Agustin (2017), dalam syariah Islam ada enam hal yang perlu dipenuhi ketika menawarkan sebuah produk, yaitu:

- Produk yang dijual dibutuhkan oleh semua orang

- Produk yang ditawarkan memiliki kejelasan barang, kejelasan ukuran atau takaran, kejelasan komposisi, dan menggunakan bahan yang baik.

- Produk yang dijual tidak rusak dan cacat.

- Produk yang diperjualbelikan adalah produk yang halal.

- Produk yang diperjualbelikan tidak mengandung unsur gharar dan penipuan.

- Produk yang dijual tidak mencampur antara kualitas yang rendah dan baik.

\section{Price (Harga)}

Menurut Priansa (2017), harga adalah sejumlah nilai yang ditukarkan konsumen dengan manfaat memiliki atau menggunakan produk yang nilainya ditetapkan oleh pembeli dan penjual melalui tawar menawar atau ditetapkan oleh penjual untuk satu harga yang sama terhadap semua pembeli. Penetapan harga dan persaingan harga telah dinilai sebagai masalah utama yang dihadapi oleh perusahaan.

Definisi harga adalah sejumlah uang yang akan dikeluarkan untuk memperoleh atau menikmati sebuah barang atau jasa. Secara lebih luas harga adalah keseluruhan nilai yang ditukarkan konsumen untuk mendapatkan keuntungan dari kepemilikan terhadap sebuah produk atau jasa. Dalam konsep Islam seorang pebisnis boleh menetapkan harga untuk suatu produk atau jasa. Namun demikian, dalam penetapan harga tidak boleh harga yang terlalu tinggi sehingga dapat memberatkan dan merugikan konsumen (Agustin, 2017).

Menurut (Huda, Hudori, Fahlevi, Badrussa'diyah, Mazaya dan sugiarti,2017), penetapan harga sepenuhnya ditentukan penjual. Hal ini menjadikan komponen bauran pemasaran syariah ini menjadi sumber penghasilan dan keuntungan bagi penjual. 
Pemasaran syariah mengatur penetapan harga uang sesuai dengan perspektif Islam. Aturan penetapan harga tersebut sebagai berikut:

Seorang penjual dilarang menjual pada harga yang lebih tinggi daripada biaya input dan margin keuntungan. Tindakan mendapat keuntungan yang tidak wajar melalui penetapan harga yang tinggi tanpa adanya perubahan kualitas yang lebih baik dan penambahan kuantitas. Sama saja dengan maisir atau perjudian.

Praktik diskriminasi harga juga dilarang dalam Islam. Penjual tidak diperbolehkan menetapkan harga yang berbeda kepada dua orang pembeli atau lebih atas barang yang sama. Perlakuan semacam ini sama dengan riba.

Manipulasi harga tidak dibenarkan dalam sudut pemasaran syariah. Salah satu contoh manipulasi harga adalah pemilik berpura-pura menjadi "pembeli" atas barang yang dijualnya dengan cara memuji-muji barang miliknya, sehingga pembeli lain percaya dan rela membayar dengan harga tinggi. penimbunan produk dan pembatasan produksi yang mengakibatkan kenaikan harga sangat dilarang dalam Islam.

Perbedaan tingkat harga diantara sesama penjual dapat memengaruhi kondisi pasar secara menyeluruh. Ketika ada satu penjual dalam pasar menaikkan harga produknya di atas harga pasar atau sebaliknya, ia menjual produknya dibawah harga pasar, maka yang akan terjadi adalah distorsi pasar. Yang akan memacu kondisi ekonomi menjadi tidak efesien sehingga mengganggu agen ekonomi dalam memaksimalkan kesejahteraan mereka sendiri.

\section{Place (Saluran distribusi)}

Lokasi atau tempat berarti berhubungan dengan sistem penyampaian dalam produk dan jasa merupakan gabungan antara lokasi dan keputusan atas saluran distribusi. Ini berhubungan dengan bagaimana cara penyampaian produk dan jasa kepada konsumen. Lokasi menjadi sangat penting, perusahaan sebaiknya memilih tempat yang dekat dengan konsumen sehingga mudah dijangkau dan harus strategis (Lupiyoadi, 2017).

Dalam menentukan place atau saluran distribusi, perusahaan Islami harus mengutamakan tempat-tempat yang sesuai dengan target market, sehingga dapat efektif dan efesien. Sehingga pada intinya, dalam menentukan marketing mix harus didasari pada prinsip-prinsip keadilan dan kejujuran. Perbedaan pada bisnis Islami dan non-Islami terletak pada aturan operasional yang menjadikan halal dan haram, sehingga harus terdapat kehati-hatian dalam menjalankan strategi (Agustin, 2017).

Menurut Hassan, et al., (2012) dalam Asnawi dan Fanani (2017), dalam hal distribusi produk, perusahaan yang menerapkan prinsip bermuamalah dalam (Islam) harus mengikuti prinsip:

- Tidak memanipulasi ketersediaan produk yang berujung pada tujuan eksploitasi.

- Tidak menggunakan unsur paksaan pada saluran pemasaran.

- Tidak memobilisasi pengaruh pada salah satu reseller atau distributor yang berakibat pada terbatasnya jumlah produk yang beredar. 
Dalam konteks tempat (distribusi), Nabi Muhammad saw, melarang tindakan monopoli. Tindakan mendominasi saluran distribusi dengan maksud untuk mengatur harga adalah tindakan yang dilarang oleh ajaran Islam. Hal yang ingin ditekankan oleh Nabi saw, saat itu adalah sebuah proses distribusi haruslah sesuai dengan peraturan yang telah disepakati bersama dan tidak ada pihak yang dirugikan, baik dari pihak produsen distributor, agen, penjual eceran, maupun konsumen (Robiah, 2017).

\section{Promotion (Promosi)}

Menurut Nickels dan McHugh (2011), memberi pengertian bahwa promosi (promotion) adalah usaha-usaha para pemasar untuk memberi informasi dan mengingatkan orang-orang dalam dalam pasar sasaran mengenai produk-produk, dan membujuk konsumen untuk membeli produk yang ditawarkan.

Promosi merupakan salah satu faktor penentu keberhasilan suatu program pemasaran. Berapapun berkualitasnya suatu produk, bila konsumen belum pernah mendengarnya dan tidak yakin bahwa produk tersebut akan berguna bagi mereka, maka mereka tidak akan pernah membelinya (Hurriyati, 2015). Adapun kegiatan yang termasuk dalam aktivitas promosi adalah periklanan, personal selling, promosi penjualan, dan publisitas (Arif, 2010).

Dalam Al-Qur'an tidak ada larangan mempromosikan produk, baik barang atau jasa dengan sistem periklanan. Bahkan periklanan pun dapat digunakan untuk mempromosikan kebenaran bagaimana seharusnya usaha bisnis dalam Islam. Namun, periklanan yang berisi tentang pernyataan-pernyataan yang berlebihan termasuk kedalam bentuk penipuan. Tidak peduli apakah deskripsi pernyataan tersebut sebagai metafor atau sebagai kiasan tentu sudah pasti dilarang (Agustin, 2017). Islam sangat menganjurkan untuk berpegang teguh kepada nilai-nilai kejujuran dalam melaksanakan kegiatan ekonomi, termasuk dalam promosi.

Menurut Alma dan Priansa (2016), banyak pelaku bisnis menggunakan teknik promosi dengan memuji-muji barangnya setinggi langit dan tidak segan-segan mengdiskreditkan produk saingan. Untuk melariskan jual belinya, pedagang tidak segansegan melakukan sumpah palsu, padahal hal tersebut merusak. Juga tidak dibenarkan, para penjual main mata dengan teman-temannya agar pura-pura berminat dengan barang yang dijual dan membelinya dengan harga mahal sesuai dengan harga yang diminta penjual. Ini disebut najasi, praktik ini sangat dilarang oleh nabi Muhammad saw.

\section{Label Halal}

Menurut Wijayanti (2017), Label merupakan informasi tentang produk yang dijual. Pelabelan bertujuan memberitahukan kepada konsumen tentang unsur-unsur yang ada dalam produk. Pelabelan produk bergantung pada katagori atau jenis produk yang dijual. Dalam label itu, minimal ada informasi tentang nama brand atau merek, baru selanjutnya informasi lainnya, seperti katagori produk, formulasi, komposisi, nama perusahaan, tanggal kadaluarsa, kode produksi, klaim produk, cara pemakaian atau petunjuk pemakaian, dosis pemakaian.

Label melaksanakan beberapa fungsi. Diantaranya, label dapat mengidentifikasi produk atau merek, label juga dapat memeringkat produk, label dapat menggambarkan produk, dan label dapat mempromosikan produk melalui grafis yang menarik (Kotler dan Keller, 2009). 
Menurut Alma dan Priansa (2016), ada tiga macam bentuk labeling yang banyak digunakan oleh perusahaan, seperti:

Label grade yaitu mencantumkan keterangan tentang ciri barang secara ringkas, seperti yang dijumpai pada kemeja, ada kata-kata, jangan pakai setrika panas, cuci pakai air dingin, jangan cuci pakai sabun, bahan ini tidak perlu disetrika, anti kusut dan sebagainya.

Label deskriftif yaitu memberikan keterangan-keterangan yang lebih rinci, seperti unsur-unsur kimia yang digunakan untuk membuat suatu makanan, ukuran warna, penggunaan suatu barang dan sebagainya.

Label informasi yaitu ini sama dengan label deskriftif hanya membuat keterangan lebih lengkap lagi. Misalnya keterangan atau brosur dalam kemasan obat. Biasanya dalam dus obat, diberikan selebaran yang menerangkan tentang bahan-bahan yang digunakan, cara pemakaian obat, khasiat obat dan sebagainya.

Secara bahasa, kata "halal" berasal dari bahasa Arab yang sudah diserap menjadi bahasa Indonesia. Halal berasal dari dari kata "halla" yang berarti diijinkan, dibolehkan atau tidak dilarang, dan lawan kata dari kata haram. Ahmad al-Syarbasi menyebutkan, halal adalah segala sesuatu yang tidak dihukum bagi pelakunya atas perlakuannya, maka halal adalah segala sesuatu yang yang dibolehkan syariat atas perbuatannya (Zulham, 2018).

Label halal adalah pemberian tanda halal atau bukti tertulis sebagai jaminan produk yang halal dengan tulisan Halal dalam huruf Arab, huruf lain dan motor kode dari Menteri yang dikeluarkan atas dasar pemeriksaan halal dari lembaga pemeriksaan halal yang dibentuk oleh MUI, fatwa halal dari MUI, sertifikat halal dari MUI sebagai jaminan yang sah bahwa produk yang dimaksud adalah halal dikonsumsi serta digunakan oleh masyarakat sesuai dengan ketentuan syariah (Alfian dan Marpaung, 2017).

\section{Keputusan Pembelian}

Keputusan adalah proses penulusuran masalah yang berawal dari latar belakang masalah, identifikasi masalah hingga kepada terbentuknya kesimpulan atau rekomendasi. Rekomendasi itulah yang selanjutnya dipakai dan digunakan sebagai pedoman basis dalam pengambilan keputusan. Oleh karena itu, begitu besarnya pengaruh yang akan terjadi jika seandainya rekomendasi yang dihasilkan tersebut terdapat kekeliruan atau adanya kesalahan-kesalahan yang tersembunyi karena faktor ketidakhati-hatian dalam melakukan pengkajian masalah (Fahmi, 2018).

Menurut Kotler (2002) dalam Alim, Mawardi, Bafadhal, (2018), keputusan pembelian adalah tindakan dari konsumen untuk mau membeli atau tidak terhadap produk. Dari berbagai faktor yang mempengaruhi konsumen dalam melakukan pembelian suatu produk atau jasa, biasanya konsumen selalu mempertimbangkan kualitas, harga dan produk sudah yang sudah dikenal oleh masyarakat Berdasarkan definisi diatas disimpulkan bahwa keputusan pembelian adalah tindakan yang dilakukan konsumen untuk melakukan pembelian sebuah produk.

Menurut Suharno (2010) dalam Imantoro, Suharyono, Sunarti, (2018), keputusan pembelian adalah tahap dimana pembeli telah menentukan pilihannya dan melakukan pembelian produk, serta mengkonsumsinya. Hal ini berkaitan dalam usahanya memenuhi 
kebutuhan dengan tahap yang dilibatkan dalam mengevaluasi, memperoleh dan menggunakan produk.

Menurut Kotler (2002) dalam Sumarwan, Jauzi, Mulyana, Karno, Mawardi, Nugroho, (2011), terdapat lima tahap proses pembelian yang spesifik terdiri dari urutan kejadian berikut: pengenalan masalah kebutuhan, pencarian informasi, evaluasi alternatif, keputusan pembelian dan perilaku pasca pembelian.

\section{METODE PENELITIAN Pendekatan Penelitian}

Di dalam penelitian ini, penulis menggunakan metode kuantitatif. Metode penelitian kuantitatif dapat diartikan sebagai metode penelitian yang berlandaskan pada filsafat positivisme, digunakan untuk meneliti pada populasi tertentu, teknik pengambilan sample pada umumnya dilakukan secara random, pengumpulan data menggunakan instrumen penelitian, analisis data bersifat kuantitatif dengan tujuan untuk menguji hipotesis yang telah ditetapkan (Sugiyono, 2011).

Jenis penelitian ini adalah penelitian dengan data primer dan sekunder. Data primer adalah data yang diperoleh dari responden melalui kuesioner, kelompok fokus, dan panel, atau juga data hasil wawancara peneliti dengan narasumber.Sedangkan data sekunder adalah yang didapat dari catatan, buku, dan majalah berupa laporan keuangan publikasi perusahaan, laporan pemerintah, artikel dan lain sebagainya (Sujarweni, 2017).

\section{Populasi dan Sampel}

Populasi yang dijadikan sebagai obyek dalam penelitian ini berjumlah 600 pelanggan data dari 1-30 juni 2019 di Restoran d'BestO Bondes di Bogor. Untuk menentukan ukuran sampel dari populasi, peneliti menggunakan rumus slovin, yakni sebagai berikut (Muhamad, 2017):

$$
n=\frac{N}{N \cdot e^{2}+1}
$$

Keterangan:

$\mathrm{n}=$ ukuran sampel

$\mathrm{N}=$ ukuran populasi

$\mathrm{e}=$ tingkat kesalahan (error) yang ditoleransi (biasanya 0,01, 0,05, 0,02 atau 0,1).

Dengan menggunakan e sebesar $10 \%$ atau 0,1 , maka hasil yang didapat adalah:

$$
n=\frac{600}{1+(600)(0,1)^{2}}
$$

$n=85,71 \approx 86$ responden.

Metode pengambilan sampel yang digunakan adalah convenience sampling yaitu teknik sampling yang diambil berdasarkan yang menyenangkan saja, atau berdasarkan faktor spontanitas (Tanjung dan Devi, 2013). 


\section{Metode Analisis Data}

Analisis regresi ganda adalah metode analisis data yang digunakan oleh peneliti, bila peneliti bermaksud meramalkan bagaimana keadaan (naik turunnya) variabel dependen (kriterium), bila dua atau lebih variabel independen sebagai faktor prediktor dimanipulasi (dinaik turunkan nilainya). Jadi analisi regresi ganda akan dilakukan bila jumlah variabel independennya minimal 2 (Sugiyono, 2017)

Persamaan regresi yang digunakan dalam penelitian ini adalah:

$$
Y=a+b 1 . X 1+b 2 . X 2+e
$$

Dimana:

$Y=$ Keputusan pembelian .

$a=$ Bilangan konstan

b1,b2 = Koefisien regresi, yaitu besarnya perubahan yang terjadi pada Y jika satu unit perubahan pada variabel bebas (variabel X1 dan X2).

$$
\begin{aligned}
& \text { X1 = Bauran Pemasaran Syariah } \\
& \text { X2 = Label Halal } \\
& \text { e = Variabel residu } .
\end{aligned}
$$

Dalam penelitian ini menggunakan teknik analis regresi berganda dan uji hipotesi menggunakan uji t secara parsial dan uji F secara simultan dan uji koefesien determinasi. Selain itu juga dilakukan uji asumsi klasik yang meliputi uji normalitas, heteroskedatisitas dan uji multikolinearitas.

\section{HASil dan Pembahasan}

\section{Gambaran Umum Responden}

Gambaran umum responden penelitian akan diuraikan secara deskriptif dan dibantu dengan penyajian dalam bentuk tabel dari jumlah responden dengan membagi ke dalam beberapa tabel yaitu jenis kelamin dan kelompok usia. Uraian identitas ini diharapkan dapat memberikan gambaran yang cukup jelas tentang kondisi responden dan kaitannya dengan masalah-masalah dan tujuan penelitian.

Tabel 1 Responden Berdasarkan Jenis Kelamin

\begin{tabular}{ccc}
\hline Jenis Kelamin & Frekuensi & Persentase \\
\hline Laki-laki & 36 & $41,9 \%$ \\
Perempuan & 50 & $58,1 \%$ \\
Total & 86 & $100 \%$
\end{tabular}

Sumber: data primer yang diolah, 2019

Daritabel diatas dapat diketahui bahwa terdapat 86 orang responden, diantaranya adalah 50 responden perempuan 58,1\% dan 36 responden laki-laki 41,9\%. 
Tabel 2 Responden Berdasarkan Usia

\begin{tabular}{ccc}
\hline Usia & Frekuensi & Persentase \\
\hline$<17$ & 8 & $9,4 \%$ \\
$17-25$ & 28 & $32,6 \%$ \\
$25-35$ & 25 & $29 \%$ \\
$>35$ & 25 & $29 \%$ \\
Total & 86 & $100 \%$ \\
\hline \multicolumn{2}{c}{ Sumber: data primer yang diolah, 2019 }
\end{tabular}

Daritabel diatas dapat diketahui bahwa dari 86 orang responden, sebagian besar responden berusia 17-25 dengan jumlah 28 responden (32,6\%), kemudian usia 25-35 berjumlah 25 responden (29\%), usia >35 sebanyak 25 responden (29\%) dan yang berusia $<17$ tahun 8 responden $(9,4 \%)$.

\section{Hasil Analisis}

Uji Validitas

Uji validitas akan menguji masing-masing variabel yang digunakan dalam penelitian ini, di mana keseluruhan variabel penelitian memuat 21 pernyataan yang harus dijawab oleh responden. Adapun kriteria yang digunakan dalam menentukan valid tidaknya pernyataan yang digunakan dalam penelitian ini adalah sebagai berikut:

Uji signifikansi dilakukan dengan membandingkan nilai $r$ hitung (nilai Corrected Item Correlation) dengan nilai $\mathrm{r}$ tabel untuk degree of freedom $(\mathrm{df})=\mathrm{n}-2=86-2=84$, dan tingkat signifikasi 0,05 , maka $\mathrm{r}$ tabel dalam penelitian ini adalah $\mathrm{r}(0,05 ; 86-2=$ 0,2120). Jika $r$ hitung lebih besar dari pada $r$ tabel dan berkorelasi positif maka butir atau pertanyaan tersebut valid. Atau dengan kata lain item pertanyaan dikatakan valid apabila skor item pertanyaan memiliki korelasi yang positif signifikan dengan skor total variabel (Sujarweni, 2015). Berdasarkan analisis yang telah dilakukan, maka hasil pengujian validitas dapat ditunjukkan pada Tabel 3 sebagai berikut:

Tabel 3 Hasil Uji Validitas Variabel Penelitian

\begin{tabular}{ccccc}
\hline No. & Variabel & rhitung & rtabel & Keterangan \\
\hline 1 & & 0,543 & 0,2120 & Valid \\
2 & & 0,582 & 0,2120 & Valid \\
3 & & 0,604 & 0,2120 & Valid \\
4 & & 0,500 & 0,2120 & Valid \\
5 & Bauran & 0,581 & 0,2120 & Valid \\
6 & Pemasaran & 0,547 & 0,2120 & Valid \\
7 & Syariah $(X 1)$ & 0,620 & 0,2120 & Valid \\
8 & & 0,656 & 0,2120 & Valid \\
9 & & 0,483 & 0,2120 & Valid \\
10 & & 0,436 & 0,2120 & Valid \\
11 & & 0,463 & 0,2120 & Valid \\
\hline 12 & & 0,661 & 0,2120 & Valid \\
13 & Label Halal & 0,664 & 0,2120 & Valid \\
14 & $(X 2)$ & 0,522 & 0,2120 & Valid
\end{tabular}




\begin{tabular}{|c|c|c|c|c|}
\hline 15 & & 0,683 & 0,2120 & Valid \\
\hline 16 & & 0,668 & 0,2120 & Valid \\
\hline 17 & \multirow{5}{*}{$\begin{array}{c}\text { Keputusan } \\
\text { Pembelian }(Y)\end{array}$} & 0,728 & 0,2120 & Valid \\
\hline 18 & & 0,706 & 0,2120 & Valid \\
\hline 19 & & 0,606 & 0,2120 & Valid \\
\hline 20 & & 0,649 & 0,2120 & Valid \\
\hline 21 & & 0,455 & 0,2120 & Valid \\
\hline
\end{tabular}

Sumber: data primer yang diolah, 2019

Berdasarkan Tabel 3, dapat diketahui bahwa nilai dari $\mathrm{r}$ hitung keseluruhan indikator yang diuji bernilai positif dan lebih besar daripada nilai $r$ tabel. Maka dapat diambil kesimpulan, bahwa keseluruhan butir indikator yang digunakan dalam penelitian ini lolos dalam uji validitas dan dinyatakan valid.

Uji Realibilitas

Menurut Ghozali (2001) dalam Sujarweni (2015), Uji reliabilitas dilakukan terhadap item pertanyaan yang dinyatakan valid. Uji ini digunakan untuk mengukur suatu kuesioner yang merupakan indikator dari variabel atau konstruk. Suatu kuesioner dikatakan reliabel atau handal jika jawaban seseorang terhadap pernyataan adalah konsisten atau stabil dari waktu ke waktu. Suatu variabel dikatakan reliabel, jika nilai Cronbach Alpha > 0,60 maka reliabel. Hasil uji reliabilitas dalam penelitian ini dapat dilihat pada Tabel 4 sebagai berikut:

Tabel 4 Hasil Uji Reliabel Variabel Penelitian

\begin{tabular}{ccccc}
\hline No & Variabel & $\begin{array}{c}\text { Cronbach's } \\
\text { Alpha }\end{array}$ & $\begin{array}{c}\text { Cronbach's } \\
\text { Alpha yang } \\
\text { di } \\
\text { isyaratkan }\end{array}$ & Keterangan \\
\hline 1 & Bauran Pemasaran Syariah $(X 1)$ & 0,759 & 0,60 & Reliabel \\
2 & Label Halal $(X 2)$ & 0,642 & 0,60 & Reliabel \\
3 & Keputusan Pembelian $(Y)$ & 0,624 & 0,60 & Reliabel \\
\hline \multicolumn{4}{c}{ Sumber: Data primer yang diolah, 2019}
\end{tabular}

Sumber: Data primer yang diolah, 2019

Hasil pengujian reliabilitas pada Tabel 4 di atas menunjukkan bahwa nilai koefisien Alpha dari variabel-variabel yang diteliti menunjukkan hasil yang beragam. Akan tetapi, semua item pernyataan variabel independen (X1 dan X2) dan variabel dependen (Y) tersebut memiliki nilai koefisien Alpha lebih besar dari pada 0,60. Dengan demikian dapat disimpulkan bahwa alat ukur yang digunakan dalam penelitianini adalah reliabel.

Uji Normalitas

Pengujian normalitas dilakukan untuk mengetahui normal tidaknya suatu distribusi data. Uji normalitas dalam penelitian ini menggunakan uji KolmogorovSmirnov dengan tingkat signifikansi 5\%. Data dikatakan normal, jika nilai signifikansi ( $p$-value) untuk setiap variabel yang di analisis lebih besar dari 0.05 (Tunga, Saputra \& Wijaya, 2014).Dalam penelitian ini memiliki tiga variabel yang diantaranya dua variabel 
independen (X1 dan X2) dan satu variabel dependen (Y), Berdasarkan atas pengolahan data yang dilakukan dengan program analisis statistik IBM SPSS Statistics 16, maka hasil uji normalitas sebagai berikut:

Tabel 5 Hasil Uji Normalitas Variabel $X_{1}$ dan $X_{2}$ terhadap Variabel $Y$

\begin{tabular}{ccc}
\multicolumn{3}{c}{ One-Sample Kolmogorov-Smirnov Test } \\
\hline & & $\begin{array}{c}\text { Unstandardized } \\
\text { Residual }\end{array}$ \\
\hline \multirow{3}{*}{ Normal Parametersa } & Mean & 86 \\
& Std. Deviation & .0000000 \\
Most Extreme Differences & Absolute & 1.62287753 \\
& Positive & .057 \\
& Negative & .057 \\
Kolmogorov-Smirnov Z & .055 \\
Asymp. Sig. (2-tailed) & .942 \\
\hline
\end{tabular}

a. Test distribution is Normal.

Sumber: Data primer yang diolah menggunakan SPSS 16, 2019

Berdasarkan uji normalitas variabel $\mathrm{X}_{1}$ dan $\mathrm{X}_{2}$ terhadap variabel $\mathrm{Y}$ dengan kolmogorov-smirnov test diperoleh nilai KSZ sebesar 0,529 dan asymp.sig sebesar 0,942 lebih besar dari 0,05, maka dapat disimpulkan bahwa variabel tersebut berdistribusi normal.

\section{Uji Heteroskedastisitas}

Uji Heteroskedastisitas bertujuan menguji apakah dalam model regresi tidak terjadi ketidaksamaan varian dari residual satu pengamatan ke pengamatan lain. Salah satu cara yang dapat digunakan untuk melihat adanya kasus heteroskedatisitas adalah dengan memerhatikan plot dari sebaran residual (*ZRESID) dan variabel yang diprediksikan (*ZPRED). Jika sebaran titik-titik dalam plot tidak menunjukan adanya suatu pola tertentu, maka dapat dikatakan bahwa model terbebas dari asumsi heteroskedastisitas (Gunawan, 2016).

Dalam penelitian ini memiliki tiga variabel yang diantaranya dua variabel independen (X1 dan X2) dan satu variabel dependen (Y), maka uji heteroskedastisitas dilakukan satu kali yaitu variabel X1 dan X2 terhadap variabel Y. Berdasarkan atas pengolahan data yang dilakukan dengan program analisis statistik IBM SPSS Statistics 16, maka hasil uji heteroskedastisitas sebagai berikut:

Gambar 2 Hasil Uji Heteroskedastisitas Variabel X1 dan X2 Terhadap Variabel Y

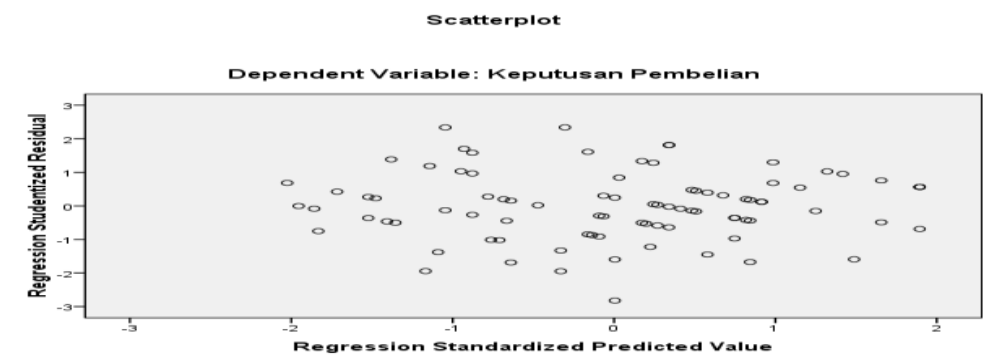


Berdasarkan pada grafik Scatterplot terlihat bahwa titik-titik menyebar secara acak serta tidak membentuk sebuah pola, dan menyebar diatas maupun dibawah angka 0 pada sumbu Y. Hal ini dapat disimpulkan uji heteroskedastisitas Variabel X1 dan X2 terhadap Variabel Y tidak terjadi heterokedastisitas.

Uji multikolinearitas

Uji multikolinearitas bertujuan untuk menguji apakah dalam model regresi ditemukan adanya korelasi antar variabel independennya. Uji multikolinearitas dalam penelitian ini menggunakan nilai tolarance dan VIF. Dengan melihat nilai tolerance sendiri lebih besar 0,10 maka dapat disimpulkan tidak terjadi multikoliniertas sera melihat nilai VIF jika nilai kurang dari 10, maka kita akan mendapatkan kesimpulan bahwa data yang kita uji tidak terjadi multikoliniertas (Tunga, Saputra \& Wijaya, 2014). Data ini dikelola melalui SPPS 16:

Tabel 6. Hasil Uji Multikolinearitas Variabel X1 dan X2 terhadap Variabel Y

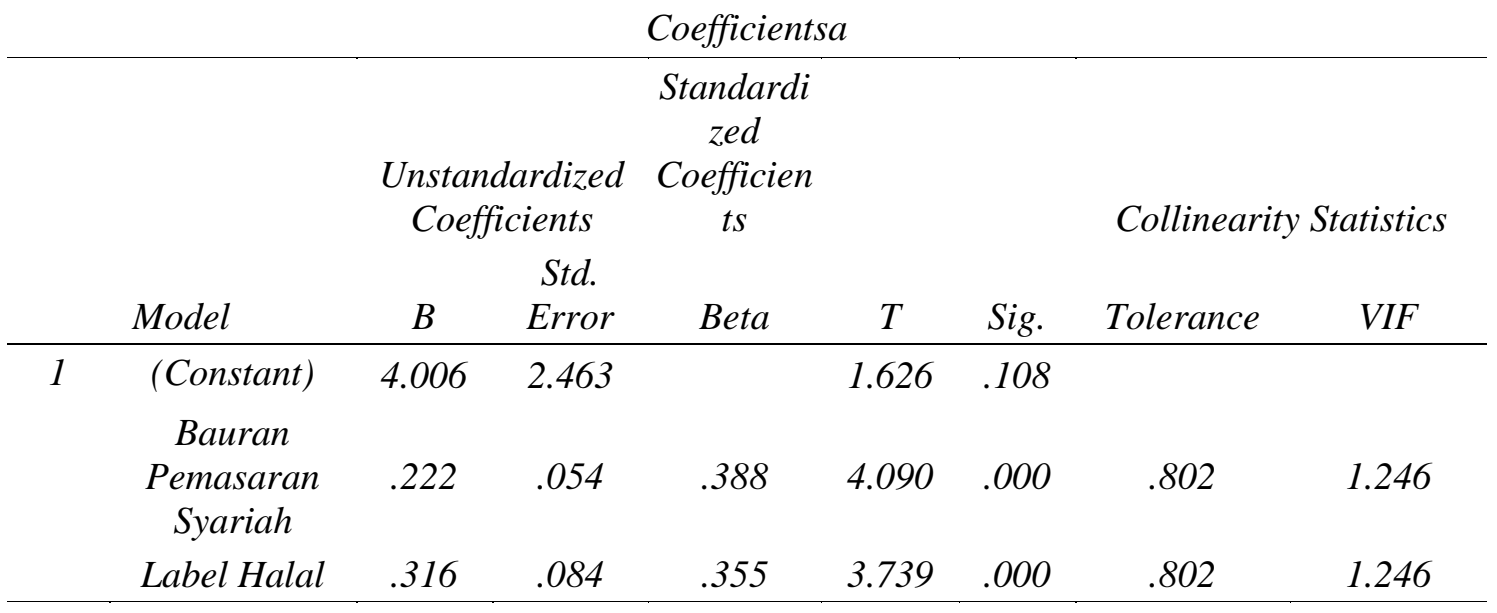

a. Dependent Variable: Keputusan

Pembelian

Sumber: Data primer yang diolah menggunakan SPSS 16, 2019

Berdasarkan tabel di atas menunjukan bahwa nilai tolerance sendiri lebih besar 0,10, maka dapat disimpulkan tidak terjadi multikoliniertas serta melihat nilai VIF kurang dari 10, maka kita akan mendapatkan kesimpulan bahwa data yang kita uji tidak terjadi multikolinearitas.

Analis Regresi Linear Berganda 
Tabel 7. Hasil Analisis Regresi Linier Berganda

\begin{tabular}{ccccccc}
\multicolumn{8}{c}{ Coefficientsa } \\
\hline \multicolumn{8}{c}{ Standardized } \\
Unstandardized Coefficients & Coefficients & & \\
& Model & $B$ & Std. Error & Beta & $T$ & Sig. \\
\hline 1 & (Constant) & 4.006 & 2.463 & & 1.626 & .108 \\
& Bauran Pemasaran & .222 & .054 & .388 & 4.090 & .000 \\
Syariah & Label Halal & .316 & .084 & .355 & 3.739 & .000 \\
\hline
\end{tabular}

a. Dependent Variable: Keputusan Pembelian

Sumber: Data primer yang diolah menggunakan SPSS 16, 2019

Berdasarkan pada hasil analisis yang telah dilakukan pada tabel diatas diperoleh koefisien untuk variabel bebas $\left(\mathrm{X}_{1}\right)=0,222$ dan $\left(\mathrm{X}_{2}\right)=0,316$ terhadap variabel terikat $(Y)=4,006$, sehingga model persamaan regresi yang terbentuk adalah sebagai berikut:

$$
Y=4,006+0,222 X_{1}+0,316 X_{2}
$$

Dimana :

$\mathrm{Y}=$ Variabel terikat (Keputusan Pembelian Y).

$\mathrm{X}_{1}=$ Variabel Bebas (Bauran Pemasaran Syariah $\mathrm{X}_{1}$ )

$\mathrm{X}_{2}=$ Variabel Bebas (Label Halal $\mathrm{X}_{2}$ )

Dari persamaan di atas, dapat dijelaskan sebagai berikut:

Nilai konstanta sebesar 4,006, mengandung arti bahwa nilai konstanta variabel Keputusan Pembelian.

Koefisien regresi pada variabel Bauran Pemasaran Syariah $\left(\mathrm{X}_{1}\right)$ sebesar 0,222 menyatakan bahwa setiap penambahan $1 \%$ nilai Bauran Pemasaran Syariah, maka nilai Keputusan Pembelian (Y) bertambah sebesar 0,222. Koefisien regresi tersebut bernilai positif, sehingga dapat dikatakan bahwa arah pengaruh variabel Bauran Pemasaran Syariah $\left(\mathrm{X}_{1}\right)$ terhadap Keputusan Pembelian (Y) adalah positif.

Koefisien regresi pada variabel Label Halal $\left(\mathrm{X}_{2}\right)$ sebesar 0,316 menyatakan bahwa setiap penambahan $1 \%$ nilai Label Halal, maka nilai Keputusan Pembelian (Y) bertambah sebesar 0,316. Koefisien regresi tersebut bernilai positif, sehingga dapat dikatakan bahwa arah pengaruh variabel Label Halal $\left(\mathrm{X}_{2}\right)$ terhadap Keputusan Pembelian (Y) adalah positif. 
Uji T (Uji Parsial)

Tabel 7. Hasil Uji T Hitung Variabel $X_{1}$ dan $X_{2}$ terhadap Variabel $Y$

\begin{tabular}{|c|c|c|c|c|c|c|}
\hline & & Unstandar & Coefficients & $\begin{array}{l}\text { Standardized } \\
\text { Coefficients }\end{array}$ & & \\
\hline & Model & $B$ & Std. Error & Beta & $T$ & Sig. \\
\hline \multirow[t]{3}{*}{1} & (Constant) & 4.006 & 2.463 & & 1.626 & .108 \\
\hline & $\begin{array}{c}\text { Bauran Pemasaran } \\
\text { Syariah }\end{array}$ & .222 & .054 & .388 & 4.090 & .000 \\
\hline & Label Halal & .316 & .084 & .355 & 3.739 & .000 \\
\hline
\end{tabular}

a. Dependent Variable: Keputusan Pembelian

Sumber: Data primer yang diolah menggunakan SPSS 16, 2019

Menurut Setyani (2015), dasar pengambilan keputusan adalah sebagai berikut:

Ho : $\beta 1=0$; tidak terdapat pengaruh antara bauran pemasaran syariah terhadap keputusan pembelian.

Ha : $\beta 1 \neq 0$; terdapat pengaruh antara bauran pemasaran syariah terhadap keputusan pembelian.

Dasar keputusan :

Apabila $\mathrm{t}$ hitung $>\mathrm{t}$ table maka Ho ditolak dan Ha diterima.

Apabila t hitung < t table maka Ho diterima dan Ha ditolak.

Uji T hitung (uji parsial) variabel $\mathrm{X}_{1}$ terhadap variabel Y

Nilai $\mathrm{t}$ tabel dapat dilihat pada tabel statistik tingkat signifikan 0,05 dengandf $=$ $(\alpha / 2 ; \mathrm{n}-\mathrm{k}-1)$ atau $(0,05 / 2 ; 86-1-1)=84$. $\mathrm{t}$ tabel sebesar 1,988 . Hasil analisis uji $\mathrm{t}$ variabel $\mathrm{X}_{1}$ terhadap variabel $\mathrm{Y}$ adalah sebagai berikut:

Dari tabel di atas dapat dilihat bahwa nilai t hitung pada variabel bauran pemasaran syariah adalah 4,090 dengan tingkat signifikansi sebesar 0,000. Karena nilai t hitung lebih besar dari t tabel yaitu 4,090 > 1,988 dan nilai signifikansinya $0,000<0,05$ maka Ho ditolak dan $\mathrm{H} 1$ diterima. Berdasarkan hasil ini dapat disimpulkan bahwa veriabel Bauran Pemasaran Syariah $\left(\mathrm{X}_{1}\right)$ berpengaruh positif dan signifikan terhadap kepetusan pembelian (Y) pada Restoran d'BestO. Artinya semakin tinggi strategi bauran pemasaran syariah maka semakin tinggi pula keputusan pembelian terhadap Restoran d'BestO.

Uji T hitung (uji parsial) variabel $\mathrm{X}_{2}$ terhadap variabel $\mathrm{Y}$

Nilai t tabel dapat dilihat pada tabel statistik tingkat signifikan 0,05 dengan $\mathrm{df}=$ $(\alpha / 2 ; \mathrm{n}-\mathrm{k}-1)$ atau $(0,05 / 2 ; 86-1-1)=84$. $\mathrm{t}$ tabel sebesar 1,988 . Hasil analisis uji $\mathrm{t}$ variabel $\mathrm{X}_{2}$ terhadap variabel $\mathrm{Y}$ adalah sebagai berikut:

Dari tabel di atas dapat dilihat bahwa nilai thitung pada variabel label halal adalah 3,739 dengan tingkat signifikansi sebesar 0,000. Karena nilai t hitung lebih besar dari t tabel yaitu 3,739 > 1,988 dan nilai signifikansinya 0,000 < 0,05 maka Ho ditolak dan H1 diterima. Berdasarkan hasil ini dapat disimpulkan bahwa veriabel label halalberpengaruh positif dan signifikan terhadap keputusan pembelian pada Restoran d'BestO Bogor. Artinya semakin tinggi tingkat keyakinan label halal pada konsumen d'BestO maka semakin tinggi pula keputusan pembelian terhadap Restoran d'BestO Bogor. 


\section{Uji Simultan (Uji F)}

Uji statistik $\mathrm{F}$ digunakan untuk menguji apakah variabel independen yang dimasukkan dalam model memiliki pengaruh secara bersama-sama (simultan) terhadap variabel dependen. Penelitian ini menggunakan tingkat signifikansi $(\alpha) 5 \%$ atau derajat kebebasan (degree of freedom) 95\%. Dengan demikian, apabila nilai probabilitas statistik lebih kecil dari $(\alpha) 5 \%$, maka model dapat digunakan untuk memprediksi pengaruh variabel independen secara bersama-sama terhadap variabel dependen (Tunga, Saputra \& Wijaya, 2014).

Tabel 8. Hasil Uji F Hitung Variabel $X_{1}$ dan $X_{2}$ terhadap Variabel $Y$

\begin{tabular}{ccccccc}
\multicolumn{8}{c}{ ANOVAb } \\
\hline & Model & Sum of Squares & $D f$ & Mean Square & $F$ & Sig. \\
\hline \multirow{4}{*}{1} & Regression & 148.889 & 2 & 74.444 & 27.601 & $.000 a$ \\
& Residual & 223.867 & 83 & 2.697 & & \\
& Total & 372.756 & 85 & & & \\
\hline
\end{tabular}

a. Predictors: (Constant), Label Halal, Bauran Pemasaran Syariah

b. Dependent Variable: Keputusan Pembelian

Sumber: Data primer yang diolah menggunakan SPSS 16, 2019

$\mathrm{H}_{0} \quad$ : Tidak ada pengaruh positif yang signifikan secara bersama-sama antara bauran pemasaran syariah dan label halal terhadap keputusan pembelian.

$\mathrm{H}_{1} \quad$ : Ada pengaruh positif yang signifikan secara bersama-sama antara bauran pemasaran syariah dan label halal terhadap keputusan pembelian.

Dari tabel di atas dapat dilihat bahwa jika dilihat dari nilai Sig. F menyatakan variabel bauran pemasaran syariah dan label halal terhadap keputusan pembelian sebesar 0,000 lebih kecil dari nilai signifikasi $0,000<0,05$ maka $\mathrm{H}_{0}$ di tolak dan $\mathrm{H}_{1}$ diterima sehingga berdasarkan hasil ini maka ada pengaruh positif yang signifikan secara bersamasama antara bauran pemasaran syariah dan label halal terhadap keputusan pembelian.

Koefisien Determinasi $\boldsymbol{R}^{2}$

Analisis koefisien determinasi dilakukan untuk mengetahui seberapa besar nilai presentase kontribusi variabel bebas terhadap variabel terikat. Dari hasil perhitungan melalui program analisis statistik IBM SPSS Statistics 16 didapatkan nilai koefisien determinasi sebagai berikut :

Tabel 9. Hasil Koefisien Determinasi Variabel $X_{1}$ dan $X_{2}$ terhadap Variabel $Y$

\begin{tabular}{ccccc}
\multicolumn{5}{c}{ Model Summaryb } \\
\hline Model & $R$ & $R$ Square & $\begin{array}{c}\text { Adjusted } R \\
\text { Square }\end{array}$ & $\begin{array}{c}\text { Std. Error of } \\
\text { the Estimate }\end{array}$ \\
\hline 1 & $.632 a$ & .399 & .385 & 1.642 \\
\hline a. Predictors: (Constant), Label Halal, Bauran Pemasaran \\
Syariah \\
\multicolumn{4}{c}{ b. Dependent Variable: Keputusan Pembelian }
\end{tabular}

Sumber: Data primer yang diolah menggunakan SPSS 16, 2019 
Sebagaimana telah di deskripsikan dalam tabel statistik model summary diketahui nilai koefisien determinasi adalah sebesar 0,399 , hal itu mengasumsikan bahwa variasi perubahan variabel keputusan pembelian (Y) dipengaruhi oleh perubahan variabel bebas bauran pemasaran syariah (X1) dan label halal (X2) sebesar 39,90\%. Jadi besarnya pengaruh bauran pemasaran syariah dan label halal terhadap keputusan pembelianpada Restoran d'BestO sebesar 39,90\%, sedangkan sisanya sebesar 60,10\% dipengaruhi oleh faktor lain diluar penelitian ini.

\section{KESIMPULAN}

Berdasarkan pengujian untuk menganalisis hubungan antara variabel independen (bauran pemasaran syariah dan label halal) terhadap variabel dependen (keputusan pembelian) dapat disimpulkan bahwa,bauran pemasaran syariah berpengaruh positif dan signifikan terhadap keputusan pembelian. Terlihat $t_{\text {hitung }}(4,090)>t_{\text {tabel }}(1,988)$, dengan tingkat signifikan $0,000<0,05(5 \%)$ yang berarti berpengaruh positif dan signifikan terhadap keputusan pembelian produk makanan d'BestO pada konsumen di d'BestO Bondes Bogor. Hal ini berarti semakin tinggi bauran pemasaran syariah suatu produk, maka semakin tinggi keputusan pembelian.

Variabel label halal berpengaruh positif dan signifikan terhadap keputusan pembelian. Terlihat $t_{\text {hitung }}(3,739)>t_{\text {tabel }}(1988)$, dengan tingkat signifikan $0,000<0,005$ (5\%) yang berarti label halal berpengaruh positif dan signifikan terhadap keputusan pembelian produk makanan d'BestO pada konsumen did'BestO Bondes Bogor. Hal ini berarti semakin tinggi tingkat keyakinan label halal, maka semakin tinggi keputusan pembelian.

Variabel yang dominan mempengaruhi keputusan pembelian dalam penelitian ini adalah variabel bauran pemasaran syariah. Hal ini dapat dilihat dari uji t yang telah dilakukan menunjukkan nilai t hitung variabel bauran pemasaran syariah $(4,090)$, lebih besar dari t hitung variabel label halal $(3,739)$.

\section{REFERENSI}

Agustin, Hamdi. 2017. Studi Kelayakan Bisnis Syariah. Depok : PT RajaGrafindo Persada

Ahmed, Selim dan Habibur Rahman. 2015. The Effects Of Marketing Mix On Consumer Satisfaction: A Literature Review From Islamic Perspectives : Journal of Islamic Economics. Volume 2 (1) : 17-30

Alfian, Ian dan Muslim Marpaung. 2017. Analisis Pengaruh Label Halal, Brand dan Harga Terhadap Keputusan Pembelian di Kota Medan : Jurnal At-Tawasuth. Volume 2 (1) : 122-145

Alim, Silachul Alfinul Alim, et al.. 2018. Pengaruh Persepsi Label Halal dan Kualitas Produk Terhadap Keputusan Pembelian Produk Fesyen Muslim ( Survei pada Pelanggan Produk Zoya Muslim di Kota Malang) : Jurnal Administrasi Bisnis. Volume 62 (1) : 127-134

Alma, Buchari dan Priansa, Donni Juni. 2016. Manajemen Bisnis Syariah Edisi Revisi. Bandung : ALFABETA

Asnawi, Nur dan Fanani, Muhammad Asnan. 2017. Pemasaran Syariah Teori, Filosofi \& Isu-Isu Kontemporer. Depok : PT RajaGrafindo Persada 
Pengaruh Bauran Pemasaran Syariah dan Label Halal terhadap Keputusan Pembelian Arif, Nur Rianto Al. 2010. Dasar-Dasar Pemasaran Bank Syariah. Bandung : ALFABETA

Bulan, Tengku Putri Lindung dan Muhammad Rizal. 2016. Pengaruh Labelisasi Halal terhadap Keputusan Pembelian Sosis di Kuala Simpang Kabupaten Aceh Tamiang : Jurnal Manajemen dan Keuangan. Volume 5 (1) : 430-439

Djamil, Fathurrahman. 2013. Hukum Ekonomi Islam Sejarah, Teori dan Konsep. Jakarta : Sinar Grafika

Fahmi, Irfani. 2016. Teori dan Teknik Pengambilan Keputusan. Depok : PT Raja Grafindo Persada

Fatoni, Siti Nur. 2014. Pengantar Ilmu Ekonomi Dilengkapi Dasar-Dasar Ekonomi Islam. Bandung : Pustaka Setia

Gunawan, Imam. 2017. Pengantar Statistika Inferensial. Jakarta : PT RajaGrafindo

Gunawan, Wahyu Tri. 2013. Bauran Pemasaran dan Kualitas Pelayanan Pengaruhnya Terhadap Kepuasan Pelanggan Pada Texas Chicken Manado : Jurnal EMBA. Volume 1 (4) : 2049-2058

Heryanto, Imam. 2015. Analisis Pengaruh Produk, Harga, Distribusi, dan Promosi Terhadap Keputusan Pembelian Serta Implikasinya pada Kepuasan Pelanggan : Jurnal Ekonomi, Bisnis, \& Entrepreuneurship. Volume 9 (2) : 80-101

Huda, Nurul, et.al.. 2017. Pemasaran Syariah Teori dan Aplikasi. Depok : Kencana

Hurriyati, Ratih. 2015. Bauran Pemasaran \& Loyalitas Konsumen. Bandung : CV ALFABETA

Imantoro, Fatih, et al.. 2018. Pengaruh Citra Merek, Iklan, Dan Cita Rasa Terhadap Keputusan Pembelian (Survei Terhadap Konsumen Mi Instan Merek Indomie di Wilayah Um Al- Hamam Riyadh) : Jurnal Administrasi Bisnis. Volume 57 (1) : 180-187

Istianah, et al.. 2018. Analisis Sharia Marketing Mix terhadap Kepercayaan Pelanggan dan Keputusan Pembelian pada Online Shop Tiws.id : An-Nisbah: Jurnal Ekonomi Syariah. Volume 5 (1) : 276-296

Kotler, Philip dan Ketler, Kevin Lane. 2009. Manajemen Pemasaran, Edisi Ketiga Belas Jilid 2. Jakarta : Erlangga

Larasati, et al.. 2019. Pengaruh Label Halal Terhadap Produk Kecantikan : Al Maal : Jurnal of Islamic Economics and Banking. Volume 1 (1) : 48-64

Lupiyoadi, Rambat. 2018. Manajemen Pemasaran Jasa Berbasis Kompetensi. Jakarta : Salemba Empat

Nickels, William G, et.al.. 2011. Pengantar Bisnis Edisi 8. Jakarta: Salemba Empat

Muhamad. 2017. Metodologi Penelitian Ekonomi Islam. Depok : PT RajaGrafindo Persada

Murtie, Afin. 2011. Strategi Gila Menjadi Marketing No.1. Bekasi : Laskar Aksara

Priansa, Donni Juni. 2017. Komunikasi Pemasaran Terpadu. Bandung : Pustaka Setia 
Rika Paujiah, Ahmad Mulyadi Kosim, \& Syarifah Gustiawati

Rafita, Helsy Zella. 2017. Pengaruh Label Halal Terhadap Keputusan Pembelian Produk Kosmetik (Studi Pada Mahasiswi Fakultas Ekonomi Dan Bisnis Islam Angkatan 20132016 UIN Raden Intan Lampung). Skripsi. Universitas Islam Negeri Raden Intan Lampung : Tidak diterbitkan.

Robiah, Faidatur. 2017. Marketing Hebat Ala Rasulullah SAW. Solo : PT Tiga Serangkai Pustaka Mandiri

Setyani, Erina. 2015. Pengaruh Marketing Mix Terhadap Keputusan Pembelian Konsumen Di Toko Alat Tulis Hadi Sutrisno Putra 2 Limpung. Skripsi. Universitas Islam Negeri Walisongo Semarang: Tidak diterbitkan

Sugiyono. 2011. Metode Penelitian Kualitatif dan $R \&$ D. Bandung : ALFABETA . 2017. Statistika Untuk Penelitian. Bandung : ALFABETA

Sujarweni, V Wiratna. 2015. Metodologi Penelitian Bisnis \& Ekonomi. Yogyakarta : Pustaka Baru Pers

Sumarwan, Ujang, et al.. 2011. Riset Pemasaran dan Konsumen. Bogor : IPB Press

Tanjung, Hendri dan Abrista Devi. 2013. Metodologi Penelitian Ekonomi Islam. Jakarta : Gramata Publishing

Tarigan, Eka Dewi Setia. 2016. Pengaruh Gaya Hidup, Label Halal Dan Harga Terhadap Keputusan Pembelian Kosmetik Wardah Pada Mahasiswa Program Studi Manajemen Fakultas Ekonomi Universitas Medan Area Medan : Jurnal Konsep Bisnis dan Manajemen. Volume 3 (1) : 47-61

Tunga, Ananta Wikrama, et.al.. 2014. Metodologi Penelitian Bisnis. Yogyakarta : Graha Ilmu

Widyaningrum, Premi Wahyu. 2018. Pengaruh Label Halal, Asosiasi Merek, Iklan, dan Celebrity Endroser terhadap Keputusan Pembelian (Survei Pada Konsumen Wardah di Malang) : Jurnal Capital. Volume 1 (2) : 111-124

Wijayanti, Titik. 2017. Marketing Plan! dalam Bisnis Third Edition. Jakarta : PT Gramedia

Zainal, Veuthzal Rivai, et al.. 2017. Islamic Marketing Management. Jakarta : PT Bumi Aksara

Zulham. 2018. Peran Negara Dalam Perlindungan Konsumen Muslim Terhadap Produk Halal. Jakarta Timur : KENCANA 